\title{
DRIFT POTENTIAL FOR LOW PRESSURE EXTERNAL MIXING TWIN FLUID NOZZLES BASED ON WIND TUNNEL MEASURMENTS
}

\author{
Sehsah, E.M.E* and A.Herbst**
}

\begin{abstract}
Wind tunnel tests provide one way in which the risk of drift from given nozzle conditions can be quantified but it is accepted that the use of field measurements and modeling approaches are also valid for determining a relative for Ex. Mix. Twin Fluid drift risk factor. The goals of present study assess the drift potential of the EMTF nozzles using wind tunnel tests, by comparing the drift profiles of sprays from EMTF nozzles those from standard fan nozzles.. As well as investigating to find the optimum combination for EMTF nozzles from the available nozzles in the marketing which may be producing the low drift. The current investigation research was carried out in the Federal Biological Research Centre for Agriculture and Forestry (JKI), Braunschweig, Germany. The wind tunnel was adapted at the optimum air conditions, $20^{\circ} \mathrm{C}$ air temperature and $80 \%$ relative humidity. Eight drift-reducing external mixing twin fluid nozzles were evaluated in a wind tunnel to compare drift. Each tip was compared at 60 and $100 \mathrm{kPa}$ liquid pressures, parallel to a 1, 2 and $3 \mathrm{~m} \mathrm{~s}^{-1}$ wind speeds, and at the $150 \mathrm{kPa}$ air pressure for each.

The results indicated that the external mixing twin fluid nozzles may be producing the low drift at low liquid pressure. The increase of liquid pressure tends to decrease the vertical drift and increase the DIX values. The optimum co-angling for EMTF nozzles was found at $45^{\circ}$ that may reduce the drift potential and fallout of spray for all treatment conditions. The N5 (Lechler FT 5-608 \& XR110ß03 VK) nozzle may be able to reduce the low fallout airborne volume flux compared to Standard ISO nozzle and N1 nozzle which produced at $43.7 \%$ DIX value. The DIX values at 100 kPa liquid pressures, co-angling $45^{\circ}$
\end{abstract}

*Dr. Sehsah, El-Sayed El-Beily, Dept. of Agric. Eng. Faculty of Agricultural, Kafr ElSheikh University, 33516-kafr El-Sheikh, Egypt E-Mail sehsah_2000@yahoo.de **Dr. Andreas Herbst, Federal Biological Research Centre for Agriculture and Forestry Braunschweig, Application Techniques Division, Messeweg 11/12, D-38104 Braunschweig, Germany E-mail: andreas.herbst@jki.bund.de. 
and wind speed $1 \mathrm{~m} \mathrm{~s}-1$ were $291.5 \%$ for N5 (Lechler FT 5-608 \& XR11003 VK) nozzle and $29.6 \%$ for the N1 (Lechler FT 5-608 \& TT110-03 POM) nozzle respectively. As well as the vertical drift for the above mentioned conditions were $1.5 \%, 1.6 \%, 1.3 \%$ and $1.2 \%$ for the EMTF nozzles N2, N3, N4 and N5 respectively The airborne values for N5 (Lechler FT 5-608 \& XR110-03 VK) nozzle were $0.71 \mathrm{ml} / \mathrm{s.mm}, 0.07$ and $0.046 \mathrm{ml} / \mathrm{s.mm}$ at ground level (zero $\mathrm{mm}), 500 \mathrm{~mm}$ and $600 \mathrm{~mm}$ height respectively.

\section{Keywords: Drift, Low pressure, nozzles}

\section{INTRODUCTION}

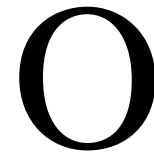

ver the last several years there has been an increased interest by nozzle manufactures to design nozzles that will effectively reduce the volume of drift-able fines found in spray droplet spectrums. This is being successfully accomplished with the use of a preorifice and also with turbulation chambers (R. Wolf, 2000). A recent trend with spray nozzle design is to incorporate a 'venturi' that includes the spray droplet in air to lessen the drift potential while still maintaining adequate efficacy. Several nozzle manufacturers are including this new design as a part of a marketing campaign for drift control. Early research would indicate that the venturi nozzle is producing larger spray droplets (Womac, et al., 1997; Ozkan and Derksen, 1998; R. Wolf, et al., 1999, 2001, 2001). Even though a better understanding of the variables associated with spray drift exists, it is still a challenging and complex research topic. Environmental variables, equipment design issues, many other application parameters, and all their interactions make it difficult to completely understand drift related issues (Smith, et al., 2000). Droplet size and spectrum has been identified as the one variable that most affects drift (SDTF, 1997). Many forces impinge on droplet size, but it is still the drop size that must be manipulated to optimize performance and eliminate associated undesirable results (Williams, et al., 1999). Drift is associated with the development of high amount of fine droplets (Gobel and Pearson, 1993).

There are many factors that control drift. These include equipment design, application parameters, physical properties of the liquid spray, type of formulation and meteorological conditions (Salyani and Cromwell 1992; 
Ganzelmeier 1993; Ganzelmeier et al., 1992). Some of the physical properties that affect spray drift are viscosity, surface tension and density of the liquid. Size of nozzle orifice, pressure, angle of the nozzle spray, nozzle design and air shear (air streams hitting the liquid) affect spray drift (Smith 1992). One of the causes of spray drift is small droplets ( 200 $\mu \mathrm{m})$ created by the nozzle. All droplets pose some drift hazard, but larger or coarser droplets have less of a chance from traveling away from the target area (Derksen and Gray. 1995; Reichard et al., 1979 and 1982). The coarse and fine droplets are more preferred because they have the least chance of drift from the target area. However, smaller droplets increase the efficacy while increasing the amount of drift. Large droplets also reduce effectiveness of the application coverage but not enough to risk the occurrence of drift. Also, large droplets may rebound from the plants surface or run off (Fox et al., 1994). When pesticides are applied, a certain part of the chemical may be drift off the target area. This may cause environmental hazards. In order to avoid inappropriate risks especially for aquatic organisms, buffer zone restrictions are given to several pesticides according to their toxicity. In some cases the pesticide cannot be approved. The width of buffer zones in arable crops, orchards, vineyards or hops is dependent on application conditions. A special system takes into account the type of adjacent water body and its bank vegetation. But the used application technique has the main influence on buffer zone width. Therefore the Federal Biological Research Centre for Agriculture and Forestry in (JKI) holds an official list of loss reducing equipment. This list contains sprayers that reduce spray drift by at least $50 \%$ in relation to a standard spraying system. Normally field tests are necessary. In case of ordinary boom sprayers, measurements in a wind tunnel on single nozzles are sufficient. These tests are done by (JKI) following a special protocol (Herbst, 2001).

The reduction of the water volume rate is an important aspect to reduce application costs. The water reduction per unit area increases the total capacity of a sprayer but it is normally linked to reduced droplet size and increased drift potential (Sehsah, 2005). One possibility to reduce water volume rate with less effect on drift is to use an atomizer with a narrow droplet size spectra. External mixing twin fluid nozzles atomizers are 
driven by air assistance nozzles. Droplet sizes are dependant on air nozzles and discharge rate organisms (Sehsah, 2005; and Sehsah and Kleisinger 2007). Application of post-emergence herbicides and Biopesticides (living organisms) are becoming an ever-increasing complex phase of crop production. More information about how to use the latest nozzle technologies to apply herbicides or Bio-pesticides for postemergence control of grasses and broadleaves is paramount for achieving optimum control of the undesired pests. The complexity of the postemergence application process is exemplified as recent nozzle technology is placing an increased emphasis on keeping the drift potential at a minimum.

The main objectives of the current research part II were to test the different low pressure external mixing twin fluid nozzles types and size in a wind tunnel, to calculate their drift potential using contrasting wind tunnel approaches and to compare these drift potential results with the reference spraying. In addition to find the optimum combinations of nozzles from different combinations of EMTF nozzles that produces the low drift. These measurements were part of a study evaluating the Developed EMTF nozzles to use in biological pesticides.

\section{MATERIAL AND METHODS}

This study was designed to measure in a wind tunnel the amount of drift from different combinations of external mixing twin fluid nozzles. The wind tunnel as shown in figure 1 was used to test the EMTF nozzles under optimum operating conditions for air temperature $20^{\circ} \mathrm{C}$ and relative humidity $80 \%$.

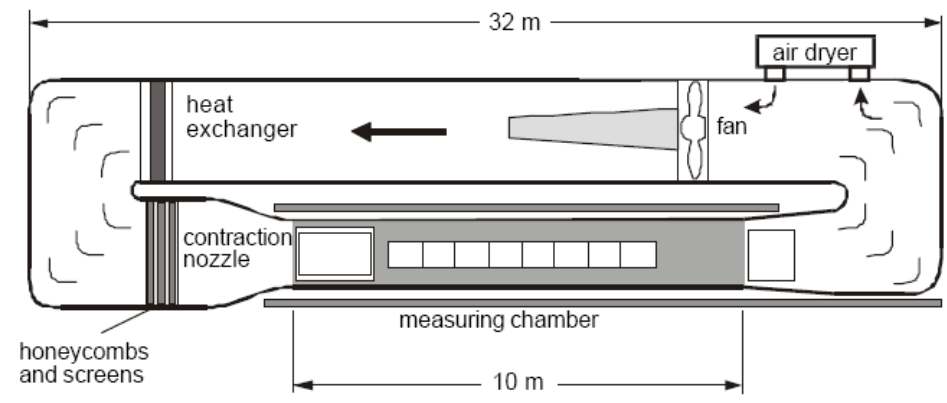

Fig. 1: The diagram of wind tunnel for testing the external mixing twin fluid nozzles. 


\section{External Mixing Twin Fluid nozzles (EMTF)}

The EMTF nozzle was developed in Hohenheim University, Germany as the part of the applicable technique for the biological material (Sehsah, 2005). We are indicat the function of an external mixing twin fluid (EMTF) nozzle in the first part of this study. The principle of the external mixing twin fluid nozzle is the injection of a liquid sheet into air sheet, both produced by tongue nozzles. At the merging line, the high-speed air stream will disintegrate the liquid sheet and produce droplets. With External mixing twin fluid nozzles, the liquid sheet or jet exposed to the atomizing air has little initial momentum and the droplets formed in atomization are entirely dependent on the kinetic energy of the atomizing air to transport them away from the nozzle into the target. The combinations of the EMTF nozzle were selected and illustrated in table 1.

\section{Experimental arrangement}

The different combinations of EMTF nozzles types (external mixing twin fluid nozzles) under test are mounted in the wind tunnel. The wind direction corresponds with the travel wind direction. The drift potential cloud is measured in a plane perpendicular to the air stream in a section 2 $\mathrm{m}$ downwind from the nozzle at wind speeds of $1 \mathrm{~m} \cdot \mathrm{s}^{-1}, 2 \mathrm{~m} \cdot \mathrm{s}^{-1}$ and $3 \mathrm{~m} \cdot \mathrm{s}^{-}$ 1. The development of the experimental approach is shown in figure 2. Passive line type drift collectors were used for the measurements. They were mounted horizontally with a spacing of $100 \mathrm{~mm}$ perpendicular to the wind direction. The single combination of EMTF nozzle, located in the center of the wind tunnel, was placed upwind $2 \mathrm{~m}$ from collectors.

Each nozzle was used individually in the tunnel and was supplied with spray from a portable sprayer fitted with calibrated digital pressure meter and an electronically controlled supply switch. Having set the spray liquid supply system for the correct pressure, an electronically controlled exposure of $15 \mathrm{~s}$ spraying was used in the experiments unless otherwise stated. This time was long enough to produce a measurable minimum deposit but without saturating any collecting lines. This avoided any loss of spray liquid retained on the collectors. However, in a few cases, when very little spray drift was being produced, the emission time was increased up to $50 \mathrm{~s}$ in order to provide detectable deposits on the collecting lines and to reduce 
variability within data sets. In addition to liquid flow rate and exposure time, other operating conditions were recorded. Relative humidity in the wind tunnel was controlled to exceed $90 \%$ to minimize the in- flight evaporation of droplets. Ambient temperature was recorded; it kept relatively constant at $\mathrm{w} 20^{\circ} \mathrm{C}$.

The first and last tests of each of the measuring sessions were carried out using the Hardi ISO F 110-03 reference nozzle at $300 \mathrm{kPa}$ to provide direct comparison with the field drift data (ISO/DIS, 2007 and Nuyttens et al., 2007a). The magnitude of deposits recovered from collector lines, varied for one and the same nozzle-pressure combination for reasons that can be attributed to the tunnel, analysis and operator skills, short sampling times and changes in nozzle performance (Miller, 1993). That is why the results from the experiments with the Hardi ISO F110-03 reference nozzle were also used as a reference set to establish that experimental procedures were within acceptable limits or not. Results from series of measurements were accepted if results from both reference sets were within their corresponding $90 \%$ confidence interval. This was the case for all the measurements reported here.

\section{Procedure and measurements:}

In total, 73 wind tunnel experiments were carried out with 867 deposit measurements including the reference spray identified as experiments a up to $\mathrm{i}$ in Table 1. Each spray application is defined by its general nozzle type Hardi standard flat-fan size ISO 03, N1, N2, N3, N4, N5 and N6 EMTF nozzles. The reference spray generated by a Hardi ISO F 110-03 standard flat- fan nozzle was used to compare the different spray applications.

The different types N1, N2, N3, N4, N5 and N6 of EMTF nozzles were compared at 60 and $100 \mathrm{kPa}$ spray pressures. The co-angling (injection angles) nozzle were $45^{\circ}$ and $60^{\circ}$ degree. As well as the different EMTF nozzles were compared at $1 \mathrm{~m} \mathrm{~s}^{-1}, 2 \mathrm{~m} \mathrm{~s}^{-1}$ and $3 \mathrm{~m} \mathrm{~s}^{-1}$ wind speed. All experiments for different EMTF nozzles were performed at an air pressure of $150 \mathrm{kPa}$. Applications using water with a single nozzle from every combination of nozzles configured for use in a wind tunnel were made. The collector was designed for removal from the wind tunnel after each treatment to facilitate drifted passive line removal and replacement with 
dry, clean Passive line for the next treatment. A soluble fluorescent tracer dye was added to the applied water. The dry collector lines were removed from the wind tunnel after application and washed with a known amount of deionized water which was then analyzed using a fluorometer. Temperature and humidity were measured using a CMP (Constant Multi Pulse) measurements probe system with data logger. The probes were positioned at boom height. Adjusting the amperage to obtained the fan motor controlled wind speed velocity.

In the laboratory of the JKI, Germany, $10 \mathrm{ml}$ of deionized water was added to each $U$ tube to wash the tracer from every collector's samples. The tracer concentration in the washing solution was determined using the fluorescence spectra SFM 25 spectrophotometer (KONTRON Instruments) to analysis the samples. The tank sample was used to calibrate the measurement. The structure of the wind tunnel and measurements of wind velocity, turbulence intensity, temperature, and relative humidity were described by Herbst, (2001).

\section{Measuring the air velocity from EMTF nozzle:}

The FC012-Micromanometer and Anemometer CLIMA was used to measure the air velocity at different outlet distance from the FT 5-608 nozzle of air. The difference pressure FC012-Micrometer instrument was used to measure the air speed from $1 \mathrm{~cm}$ to $50 \mathrm{~cm}$ because it has the higher accuracy to measure the air velocity at more than $80 \mathrm{~m} \mathrm{~s}^{-1}$. The Anemometer CLIMA was fixed at different outlet distance from $50 \mathrm{~cm}$ to $600 \mathrm{~cm}$ by increment of $50 \mathrm{~cm}$ between every measuring point. The Fig. 3 displays the result values of the measuring air velocity at different outlet distance.

We assumed that the droplet velocity may be taken the air velocity values at the outlet distance that produced by the FT5-608 nozzle. The FT5-608 nozzle of air in the EMTF nozzles was the source of the kinematics energy of the droplets after its let the liquid of nozzles. Therefore, the droplet velocities at $2 \mathrm{~cm}$ (boundary layer contact between the two fluid air and liquid) was $46.3 \mathrm{~m} \mathrm{~s}^{-1}$, at $150 \mathrm{kPa}$ air pressure as shown in Fig. 2. This higher droplet velocity may be reducing the drift and keeping the droplets to riche into the target. The hypotheses of the data analysis were to assume that the drift is affected by a number of factors and situations. 
The factors are the different EMTF nozzles types; three wind speeds (1, 2 and $3 \mathrm{~m} \mathrm{~s}^{-1}$ ) and two co-angling (injection angles, $45^{\circ}$ and $60^{\circ}$ ). These include two liquid pressure $(60 \mathrm{kPa}$ and $100 \mathrm{kPa})$, as well as pressure of air which used to atomize the liquid spray by FT 5-608 nozzle of air was adjusted at $150 \mathrm{kPa}$.

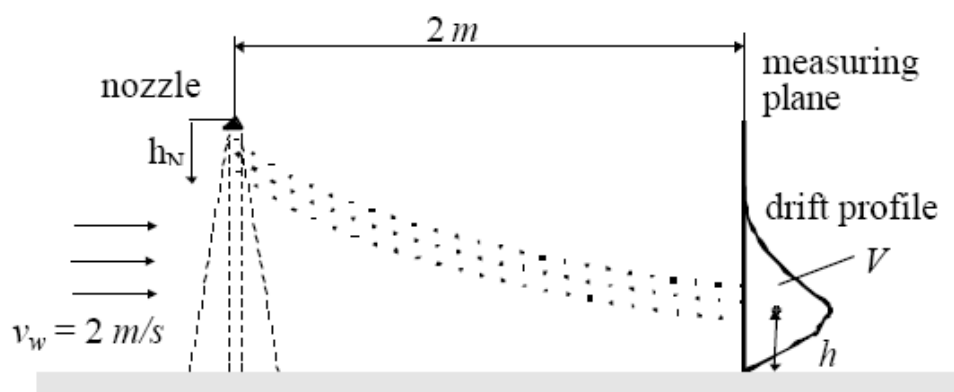

Fig. 2: Schematic of experimental arrangement in the wind tunnel for drift potential estimation.

\section{Vertical drift potential profile}

At first it was important to define a reference for the wind tunnel measurements. Since conventional $110^{\circ}$ flat fan nozzles of size 03 have been the standard in many European countries, some of them were tested first. A vertical drift potential profile was calculated from the data by integration over horizontal measuring lines (Herbst, 2001).

$$
V^{\circ}=\int_{0}^{h_{N}} \int_{0}^{\infty} V^{0}(y, z) d y d z
$$

Whereas $\mathrm{V}^{\circ}=$ volume flux at any point of the measuring plane.

Also, the relative drift potential volume is then calculated by:

Whereas $\mathrm{V}^{\circ}{ }_{\mathrm{N}}=$ nozzle output

$$
V=\frac{V^{\circ}}{V_{N}^{\circ}}
$$

The Drift Potential Index (DIX) was defined as:

$$
D I X=\frac{h^{a}}{h_{s r}^{a}} \frac{V^{b}}{V_{S r}^{b}} .100 \%
$$

$\mathrm{h}_{\mathrm{Sr}}$ and $\mathrm{V}_{\mathrm{Sr}}$ is parameters from a conventional flat fan nozzle 03@3bar. It 
is known from a regression analysis (Helck and Herbst, 1998) with wind tunnel and field measurements for a lot of nozzles that the best fit is achieved with the parameters an equal than 0.88 and $b$ equal than 0.78 .

Table 1: Overview for the different combinations of the external mixing twin fluid (EMTF) nozzles tested in wind tunnel

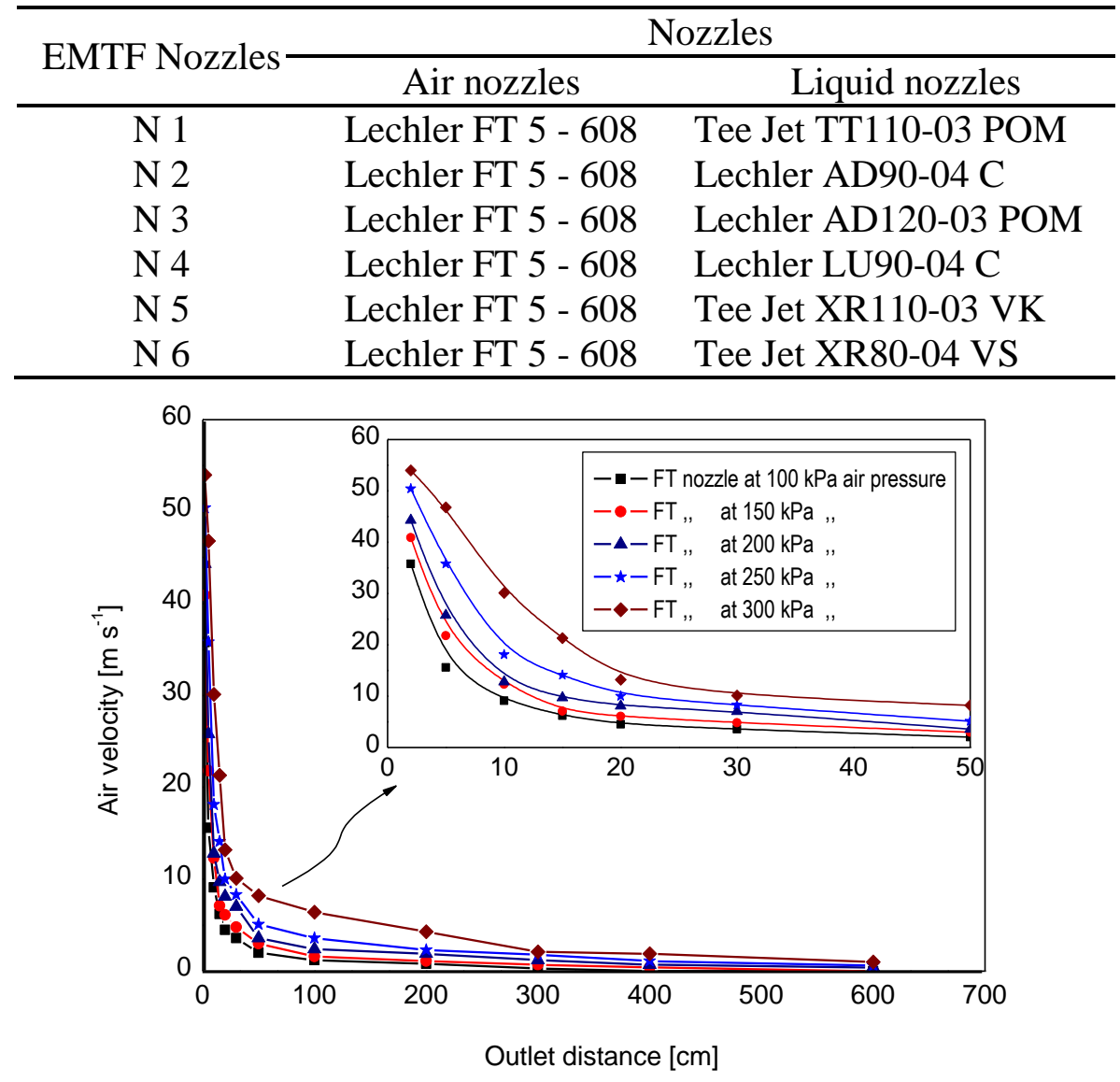

Fig. 4: External mixing twin fluid nozzle - effect of air pressure on air velocity for the tongue nozzle FT5.0-608 (Lechler)

\section{RESULTS AND DISCUSSIONS}

The Lurmark 31-03-F110 @ 3 bar is the fine/medium border nozzle of the BCPC spray classification scheme. In order to be consistent with this system, the Lurmark nozzle was chosen as the DIX reference. It has a DIX value of 100 per definition. 
The drift potential percentages values based on DIX and vertical drift percentage parameters are presented in figures 5, 6, 7, 8, 9 and 10 and. depending on the nozzle type as well as wind speed, liquid pressure and injection angles of liquid spray.

Table 2: Overview of the tested spray applications in the wind tunnel

\begin{tabular}{|c|c|c|c|c|c|c|c|}
\hline \multirow[b]{2}{*}{ Experiment } & \multirow[b]{2}{*}{$\begin{array}{l}\text { Flow- } \\
\text { rate, } \\
1 \mathrm{~min}-1\end{array}$} & \multirow[b]{2}{*}{$\begin{array}{l}\text { Exposure } \\
\text { time, s }\end{array}$} & \multicolumn{5}{|c|}{ Treatments } \\
\hline & & & Nozzles & Co-angling & $\begin{array}{l}\text { Wind } \\
\text { speed, } \\
\text { m s-1 }\end{array}$ & $\begin{array}{c}\text { Liquid } \\
\text { pressur } \\
\mathrm{e}, \\
\mathrm{k} \mathrm{Pa} \\
\end{array}$ & repetition \\
\hline i-1a* & 1.17 & 5 & $\begin{array}{c}\text { Hardi } \\
\text { ISO LD } \\
110-03\end{array}$ & - & 2 & 300 & 3 \\
\hline $2-7$ & 0.67 & 15 & N1 & $45^{\circ}, 60^{\circ}$ & $1,2,3$ & 60 & 2 \\
\hline 8- 13 & 0.50 & 15 & $\mathrm{~N} 2$ & $45^{\circ}, 60^{\circ}$ & $1,2,3$ & 60 & 2 \\
\hline $14-19$ & 0.54 & 15 & N3 & $45^{\circ}, 60^{\circ}$ & $1,2,3$ & 60 & 2 \\
\hline $20-25$ & 0.54 & 15 & N4 & $45^{\circ}, 60^{\circ}$ & $1,2,3$ & 60 & 2 \\
\hline 26- 31 & 0.71 & 15 & N5 & $45^{\circ}, 60^{\circ}$ & $1,2,3$ & 60 & 2 \\
\hline $32-37$ & 0.56 & 15 & N6 & $45^{\circ}, 60^{\circ}$ & $1,2,3$ & 60 & 2 \\
\hline $38-43$ & 1.13 & 15 & N1 & $45^{\circ}, 60^{\circ}$ & $1,2,3$ & 100 & 2 \\
\hline 44- 49 & 1.08 & 15 & $\mathrm{~N} 2$ & $45^{\circ}, 60^{\circ}$ & $1,2,3$ & 100 & 2 \\
\hline $50-55$ & 1.02 & 15 & N3 & $45^{\circ}, 60^{\circ}$ & $1,2,3$ & 100 & 2 \\
\hline $56-61$ & 1.05 & 15 & N4 & $45^{\circ}, 60^{\circ}$ & $1,2,3$ & 100 & 2 \\
\hline $62-67$ & 1.22 & 15 & N5 & $45^{\circ}, 60^{\circ}$ & $1,2,3$ & 100 & 2 \\
\hline $68-73$ & 1.05 & 15 & N6 & $45^{\circ}, 60^{\circ}$ & $1,2,3$ & 100 & 2 \\
\hline
\end{tabular}

*Hardi ISO 110 standard flat-fan nozzles; Injet, Hardi ISO Injet air-inclusion nozzles.

\section{Effect of nozzle types:}

It is clear that the types of nozzle in the external mixing twin fluid (EMTF) combined nozzles has an important influence on the reduction of the drift potential compared to the ISO 03 nozzle as shown in tables 3, 4, 5 and 6 and figures 5,6,7, and 8. In table 3, the effect of the interaction of 
different EMTF nozzles type, co-angling and wind speed were investigated to find their affecting on DIX and vertical drift. The EMTF nozzle types N2, N3, N4 and N5 produced the lowest drift and highest DIX values compared to the standard ISO nozzle, N1 and N6 at $1 \mathrm{~m} \mathrm{~s}^{-1}$. On the other hand, the N5 (Lechler FT 5-608 \& XR110ß03 VK) nozzle produced the lowest drift at $2 \mathrm{~m} \mathrm{~s}^{-1}$ compared to N1, N2, N3, N4 and N5 as well as the DIX values for same nozzle is nearly to the DIX value for standard ISO nozzle. The DIX values at $1 \mathrm{~m} \mathrm{~s}-1$ and co-angling $45^{\circ}$ were $119.7 \%, 119.4 \%, 125.5 \%$ and $149.5 \%$ for the EMTF nozzles N2, N3, N4 and $\mathrm{N} 5$, respectively. As well as the vertical drift for the above mentioned conditions were $2.2 \%, 2.1 \%, 2.0 \%$ and $1.9 \%$ for the EMTF nozzles N2, $\mathrm{N} 3$, N4 and N5, respectively A similar tendency was found in the interaction effect of types of nozzles, injection angle and liquid pressures on DIX vertical drift as shown in table 4. The DIX values at $1 \mathrm{~m} \mathrm{~s}-1$ and $100 \mathrm{kPa}$ liquid pressure were $144.6 \%, 138.8 \%, 179.9 \%$ and $196.4 \%$ for the EMTF nozzles N2, N3, N4 and N5, respectively. As well as the vertical drift for the above mentioned conditions were $1.5 \%, 1.6 \%, 1.3$ $\%$ and $1.2 \%$ for the EMTF nozzles N2, N3, N4 and N5 respectively

For the different EMTF nozzle combinations, DIX values of the N5 nozzle which combined from Lechler FT 5-608 with XR110-03VK nozzle was always higher than the DIX values compared to the standard ISO nozzle at liquid pressure $100 \mathrm{kPa}(1 \mathrm{bar})$ and $1 \mathrm{~m} \mathrm{~s}^{-1}$. As well as the differences were statistically significant. Hence, in terms of nozzle type, N5 nozzle to offer the greatest scope for reducing airborne spray and fallout flat-fan nozzles. For example, for the all EMTF nozzle combinations, DIX values at $100 \mathrm{kPa}$ liquid pressure were $134.5 \%$ for $\mathrm{N} 5$ nozzle, $25.2 \%$ for the N1 nozzle combination as shown in table 5. A similar tendency was found in the effect of the interaction of the all factors on the DIX percentage as shown in table 6. DIX values at $100 \mathrm{kPa}$ liquid pressures, co-angling $45^{\circ}$ and wind speed $1 \mathrm{~m} \mathrm{~s}^{-1}$ were $291.5 \%$ for N5 (Lechler FT 5-608 \& XR110-03 VK) nozzle and 29.6\% for the N1 (Lechler FT 5-608 \& TT110-03 POM) nozzle respectively. The fact that DIX values were higher for N5 (Lechler FT 5-608 \& XR110ß03 VK) nozzle compared with standard nozzles could only be proved statistically. Other researchers (e.g. Walklate et al., 1994 and Walklate et al., 2000) 
confirmed that low-drift nozzles and air-inclusion nozzles can reduce downwind deposits compared to conventional standard flat-fan nozzles. For example, DIX values at liquid pressure $100 \mathrm{kPa}$ and wind speed $1 \mathrm{~m}$ $\mathrm{s}^{-1}$ were $196.4 \%$ and $28.4 \%$ for N5 and N1 nozzles respectively. This is in contrast with results from the field measurements (Nuyttens et al., 2007a) and the droplet characterization (Nuyttens et al., 2007b). On the other hand, similar nozzle N5 produced the lowest vertical drift and airborne values.

It is clear that the external mixing twin fluid nozzles may be producing the low drift at low liquid pressure. It is observed that the combinations of the external mixing twin fluid nozzles gave the highly effect on the drift potential compared to the other factors, wind speed, injection angle and liquid pressures. The external mixing twin fluid nozzle N1 (TT11003+ Lechler FT 5 - 608) produced the highest drift compared to the N5 (Lechler FT 5-608 \& XR110-03 VK) nozzles combinations at low liquid pressure $100 \mathrm{kPa}$ (1 bar). It may therefore be concluded that the DIX and vertical drift are more strongly dependant on the combinations of nozzles in the EMTF nozzles, which is highly significant in data.

\section{Effect of wind speed}

In Tables 3, 4 and 6, the wind speeds were significant effect on the DIX and vertical drift for the nozzles combinations N1, N2, N3, N4, N5 and N6.. In Figs. 9 and 10, the effect of the wind speed was significant effect on the DIX and vertical drift. The increasing of the wind speeds tend to increase the drift and decrease the DIX parameter. As well as, the statistical analysis indicated that, the interaction between the wind speeds with injection angle was significant effect on the DIX and vertical drift parameters as shown in Figs. 11 and 12. This means that the wind speed is the important factor which affecting on the DIX parameter and increasing the drift potential. The DIX percent values for N5 (Lechler FT 5-608 \& XR110-03 VK) nozzle and $100 \mathrm{kPa}$ liquid pressure were $194.4 \% 83.3 \%$ and $79.3 \%$ at $1 \mathrm{~m} \mathrm{~s}^{-1}, 2 \mathrm{~m} \mathrm{~s}^{-1}$ and $3 \mathrm{~m} \mathrm{~s}^{-1}$ respectively. As well as the vertical drift percent values for above mentioned conditions were $1.2 \%$, 
$2.6 \%$ and $3.8 \%$ at wind speeds $1 \mathrm{~m} \mathrm{~s}^{-1}, 2 \mathrm{~m} \mathrm{~s}^{-1}$ and $3 \mathrm{~m} \mathrm{~s}^{-1}$ respectively. In table 6 presented that the most EMTF nozzles N2, N3, N4 and N5 gave the highest DIX values and lowest drift values compared to the N1, N6 and standard ISO nozzles at $1 \mathrm{~m} \mathrm{~s}^{-1}$ wind speed. Therefore, the droplets velocity was $46.3 \mathrm{~m} \mathrm{~s}^{-1}$ and it is able to reduce the spray fallout. As well as, this result means that, it may be able to reduce the drift and fallout of spray by using these combined in EMTF nozzles. At wind speed condition $2 \mathrm{~m} \mathrm{~s}^{-1}$, the DIX parameter for the combined N5 (Lechler FT5608 \& XR110-03 VK) nozzle tends to be as the DIX values for standard ISO nozzle.

\section{Effect of liquid pressure:}

In Tables 4, 5 and 6, the air pressure was significant effect on both parameters DIX and vertical drift percentage for all combined of EMTF nozzles N1, N2, N3, N4, N5 and N6. In figs. 11, and 12, the increase of liquid pressure tends to decrease of the vertical drift and increase the DIX values. As well as, the statistical analysis indicated that, the interaction between the low liquid pressures with injection angle was significant effect on both parameters DIX and vertical drift as shown in table 5. The DIX percent values for N5 (Lechler FT 5-608 \& XR110-03 VK) nozzle and wind speed $1 \mathrm{~m} \mathrm{~s}^{-1}$ were $77 \%$ and $196.4 \%$ at liquid pressure $60 \mathrm{kPa}$ and $100 \mathrm{kPa}$, respectively. As well as the vertical drift percent values for above nozzle were $2.9 \%$ and $1.2 \%$ at liquid pressure $60 \mathrm{kPa}$ and 100 $\mathrm{kPa}$, respectively.

It is clearly that the liquid pressure is also one importance factor affecting on the reducing of drift percentage. The liquid pressure $100 \mathrm{kPa}$ produced the lowest vertical drift and highest DIX values for N5 (Lechler FT5-608 \& XR110-03 VK) compared to $60 \mathrm{kPa}$ liquid pressure for same nozzle. The DIX percent values for N5 (Lechler FT 5-608 \& XR110-03 VK) nozzle and $45^{\circ}$ co-angling were $52.2 \%$ and $134.27 \%$ at liquid pressure $60 \mathrm{kPa}$ and $100 \mathrm{kPa}$ respectively. As well as the vertical drift percent values for above nozzle and $45^{\circ}$ co-angling were $4.63 \%$ and $1.93 \%$ at liquid pressure $60 \mathrm{kPa}$ and $100 \mathrm{kPa}$ respectively. In generally, the 
increasing of the liquid pressure tends to reduce the fallout spray and produce the low drift.

Table 3: Shows the effect of the interaction of EMTF nozzles, co-angling and wind speed on the potential drift and Dix parameter

\begin{tabular}{|c|c|c|c|c|c|c|c|}
\hline \multirow{3}{*}{ Nozzles } & \multirow{3}{*}{$\begin{array}{c}\text { Co- } \\
\text { angling }\end{array}$} & \multicolumn{6}{|c|}{ Wind speed } \\
\hline & & \multicolumn{2}{|c|}{$1 \mathrm{~m} \mathrm{~s}^{-1}$} & \multicolumn{2}{|c|}{$2 \mathrm{~m} \mathrm{~s}^{-1}$} & \multicolumn{2}{|c|}{$3 \mathrm{~m} \mathrm{~s}^{-1}$} \\
\hline & & $\begin{array}{c}\text { DIX, } \\
\%\end{array}$ & $\begin{array}{c}\text { Drift, } \\
\%\end{array}$ & $\begin{array}{c}\text { DIX, } \\
\%\end{array}$ & $\begin{array}{c}\text { Drift, } \\
\%\end{array}$ & $\begin{array}{c}\text { DIX, } \\
\%\end{array}$ & $\begin{array}{c}\text { Drift, } \\
\%\end{array}$ \\
\hline \multirow{2}{*}{ N1 } & $45^{\circ}$ & 39.2 & 6.0 & 37.1 & 6.3 & 35.8 & 6.7 \\
\hline & $60^{\circ}$ & 35.9 & 6.5 & 34.0 & 6.9 & 32.8 & 7.3 \\
\hline \multirow{2}{*}{$\mathrm{N} 2$} & $45^{\circ}$ & 116.7 & 2.2 & 38.7 & 6.7 & 28.6 & 8.5 \\
\hline & $60^{\circ}$ & 108.1 & 2.4 & 35.7 & 7.3 & 26.5 & 9.1 \\
\hline \multirow{2}{*}{ N3 } & $45^{\circ}$ & 119.4 & 2.1 & 45.7 & 5.3 & 34.4 & 6.7 \\
\hline & $60^{\circ}$ & 110.2 & 2.3 & 42.0 & 5.7 & 31.5 & 7.2 \\
\hline \multirow{2}{*}{ N4 } & $45^{\circ}$ & 125.5 & 2.0 & 49.9 & 5.4 & 42.8 & 5.9 \\
\hline & $60^{\circ}$ & 115.1 & 2.2 & 45.0 & 5.9 & 39.7 & 6.5 \\
\hline \multirow{2}{*}{ N5 } & $45^{\circ}$ & 149.6 & 1.9 & 65.5 & 3.9 & 65.5 & 4.1 \\
\hline & $60^{\circ}$ & 124.8 & 2.0 & 53.3 & 4.9 & 49.4 & 5.2 \\
\hline \multirow{2}{*}{ N6 } & $45^{\circ}$ & 65.8 & 3.4 & 56.0 & 4.0 & 37.3 & 6.1 \\
\hline & $60^{\circ}$ & 89.4 & 2.9 & 54.1 & 4.3 & 43.6 & 5.0 \\
\hline DI & & 7.085 & & drift & & 0.354 & \\
\hline $5 \% \operatorname{LSD}$ fo & DIX & 22.327 & & SD for & & 1.117 & \\
\hline
\end{tabular}

\section{Effect of the co-angling}

In table 3,5 and 6, the co-angling (injection angle) was significant effect on the reduction of potential drift for the N1, N3, N4, N5 and N6 nozzles. On the other hand, the increase of injection angle tends to increase the drift potential. The injection angle $60^{\circ}$ at $60 \mathrm{kPa}(0.6 \mathrm{bar})$ spray pressure gave the highest value of the drift potential characteristics as shown in figures 7, 9, 10 and 12. As well as, it was found that the $45^{\circ}$ at $60 \mathrm{kPa}(0.6$ bar) gave a highly effect compared to the $60^{\circ}$ injection angle at same condition. A similar trend was found for the effect of the $45^{\circ}$ at $100 \mathrm{kPa}$ liquid pressures on the DIX and vertical drift. In figures 11 and 12 presented that the interaction of the effect of the injection angle and liquid 
pressure was significant affecting on the DIX and vertical drift. The optimum co-angling for EMTF nozzles was found at $45^{\circ}$ that may be reduce the drift potential and fallout of spray for all treatment conditions. The DIX percent values for N5 (Lechler FT 5-608 \& XR110-03 VK) nozzle and wind speed $1 \mathrm{~m} \mathrm{~s}^{-1}$ were $149.5 \%$ and $124.8 \%$ at $45^{\circ} \mathrm{co}-$ angling and $60^{\circ}$ respectively. As well as the vertical drift percent values for above nozzle at $100 \mathrm{kPa}$ liquid pressure and wind speed $1 \mathrm{~m} \mathrm{~s}^{-1}$ were $1.9 \%$ and $2 \%$ at $45^{\circ}$ co-angling and $60^{\circ}$ respectively.

In addition to, the DIX percent values for N5 (Lechler FT 5-608 \& XR110-03 VK) nozzle and $100 \mathrm{kPa}$ liquid pressure were $134.27 \%$ and $105.3 \%$ at $45^{\circ}$ and $60^{\circ}$ co-angling respectively. As well as the vertical drift percent values for above nozzle at $100 \mathrm{kPa}$ liquid pressure and wind speed $1 \mathrm{~m} \mathrm{~s}^{-1}$ were $1.93 \%$ and $2.47 \%$ at $45^{\circ}$ and $60^{\circ}$ co-angling respectively.

Table 4: The effect of the interaction of EMTF nozzles, spray pressure and wind speed on the potential drift and Dix parameter

\begin{tabular}{|c|c|c|c|c|c|c|c|}
\hline \multirow{3}{*}{ Nozzles } & \multirow{3}{*}{$\begin{array}{c}\text { Pressure, } \\
\mathrm{kPa}\end{array}$} & \multicolumn{6}{|c|}{ Wind speed } \\
\hline & & \multicolumn{2}{|c|}{$1 \mathrm{~m} \mathrm{~s}^{-1}$} & \multicolumn{2}{|c|}{$2 \mathrm{~m} \mathrm{~s}^{-1}$} & \multicolumn{2}{|c|}{$3 \mathrm{~m} \mathrm{~s}^{-1}$} \\
\hline & & $\begin{array}{c}\text { DIX, } \\
\%\end{array}$ & $\begin{array}{c}\text { Drift, } \\
\%\end{array}$ & $\begin{array}{c}\text { DIX, } \\
\%\end{array}$ & $\begin{array}{c}\text { Drift, } \\
\%\end{array}$ & $\begin{array}{c}\text { DIX, } \\
\%\end{array}$ & $\begin{array}{c}\text { Drift, } \\
\%\end{array}$ \\
\hline \multirow{2}{*}{ N1 } & 60 & 28.4 & 7.7 & 26.6 & 8.3 & 24.2 & 9.1 \\
\hline & 100 & 46.7 & 4.7 & 44.6 & 4.9 & 44.4 & 4.9 \\
\hline \multirow{2}{*}{$\mathrm{N} 2$} & 60 & 80.2 & 2.7 & 22.5 & 9.7 & 19.1 & 11.5 \\
\hline & 100 & 144.6 & 1.6 & 52.0 & 4.2 & 35.9 & 6.1 \\
\hline \multirow{2}{*}{ N3 } & 60 & 90.8 & 2.4 & 30.8 & 7.1 & 26.3 & 8.3 \\
\hline & 100 & 138.8 & 1.6 & 56.8 & 3.9 & 39.7 & 5.5 \\
\hline \multirow{2}{*}{ N4 } & 60 & 60.8 & 3.7 & 26.4 & 8.2 & 26.5 & 8.4 \\
\hline & 100 & 179.9 & 1.3 & 68.5 & 3.2 & 56.1 & 3.9 \\
\hline \multirow{2}{*}{ N5 } & 60 & 77.0 & 2.9 & 35.1 & 6.1 & 35.6 & 6.5 \\
\hline & 100 & 196.4 & 1.2 & 83.8 & 2.6 & 79.3 & 3.8 \\
\hline \multirow{2}{*}{ N6 } & 60 & 58.1 & 2.8 & 52.0 & 5.9 & 38.9 & 5.8 \\
\hline & 100 & 97.0 & 2.5 & 58.1 & 4.5 & 42.0 & 5.2 \\
\hline & & & $\mathrm{Se}$ & Irift & & 0.354 & \\
\hline$D$ for & & 327 & $5 \% \mathrm{I}$ & $\mathrm{SD}$ for $\mathrm{C}$ & & 1.117 & \\
\hline
\end{tabular}


Table 5: The effect of the interaction of EMTF nozzles, co-angling and spray pressure on the potential drift and Dix parameter

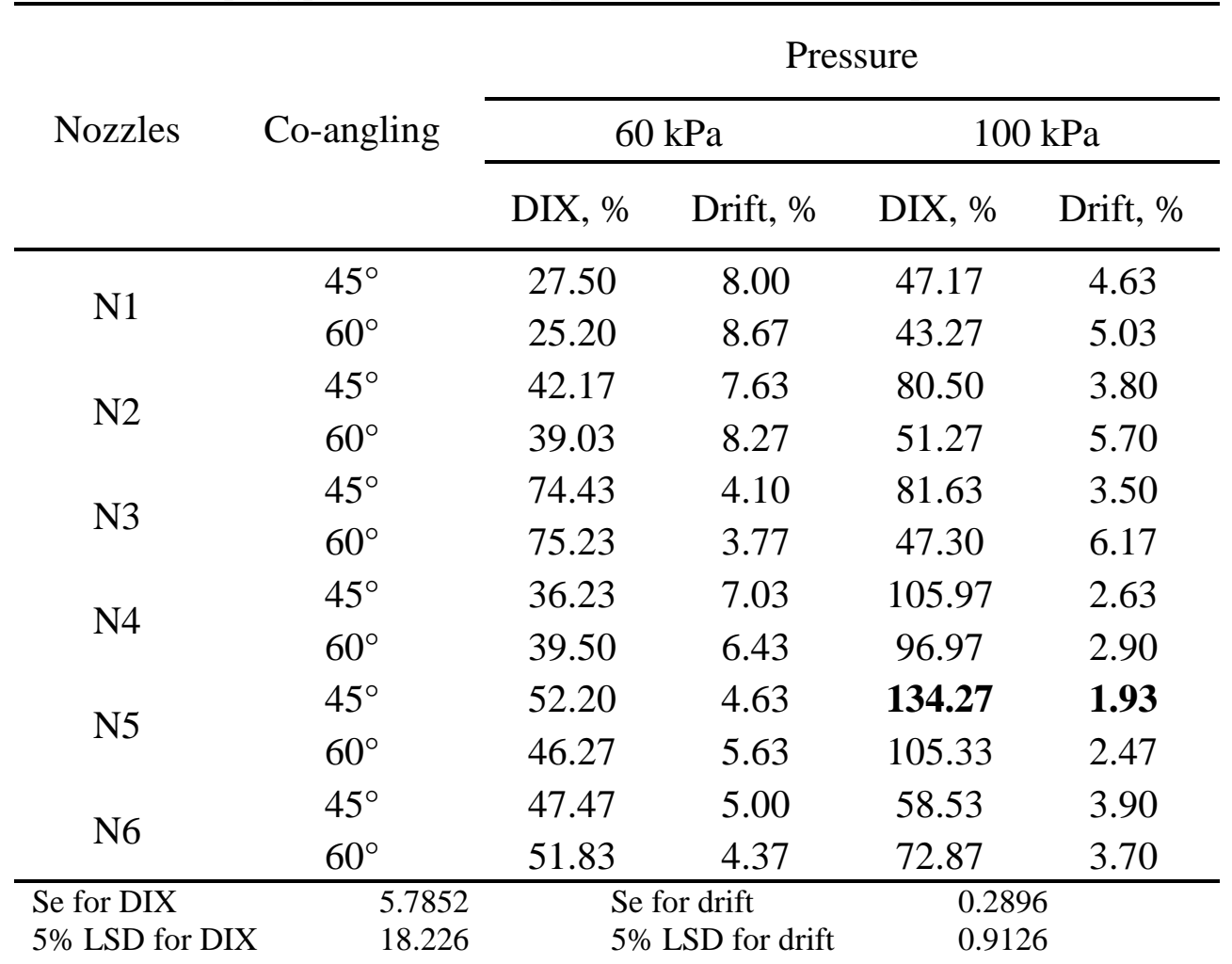

\section{Airborne volume flux deposit results:}

Average airborne volume flux deposit resulting from the different spray applications nozzles are shown in Fig. 13. This figure shows the expected fallout of airborne volume profiles for all tested nozzle types at highest DIX values parameter. The highest fallout deposits were measured closest to the nozzle with a systematic decrease with vertical distance from the nozzle. The highest airborne deposits were found at the lowest collectors with a systematic decrease with increasing height above the wind tunnel floor. The nozzle N1 with the combination (FT 5.608+TT110-03) give the highest airborne value compared to the other EMTF nozzles N2, N3, N4, N5 and N6. On the other hand, the N5 nozzle with combined (Lechler FT 5-608 \& XR110ß03 VK) produced the low fallout of airborne volume flux as well as highest airborne volume flux for N5 nozzles was at 219.5 $\%$ DIX value. 


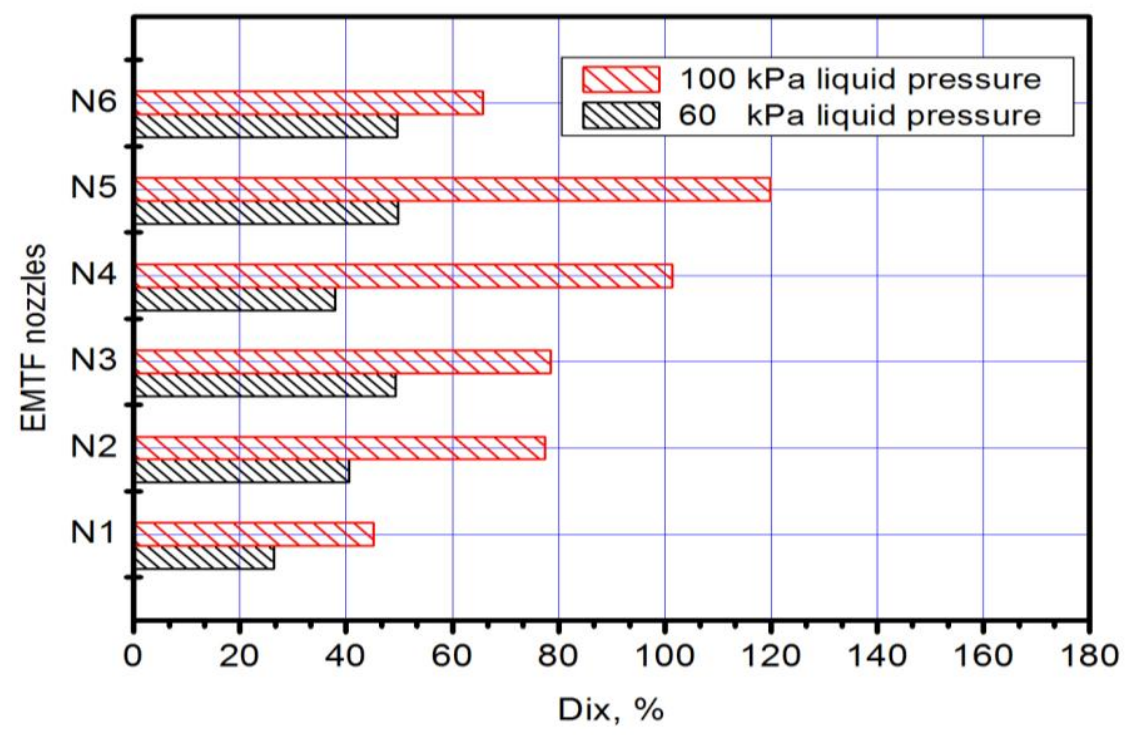

Fig. 5: Effect of liquid spray pressure on the DIX parameter for different EMTF nozzles.

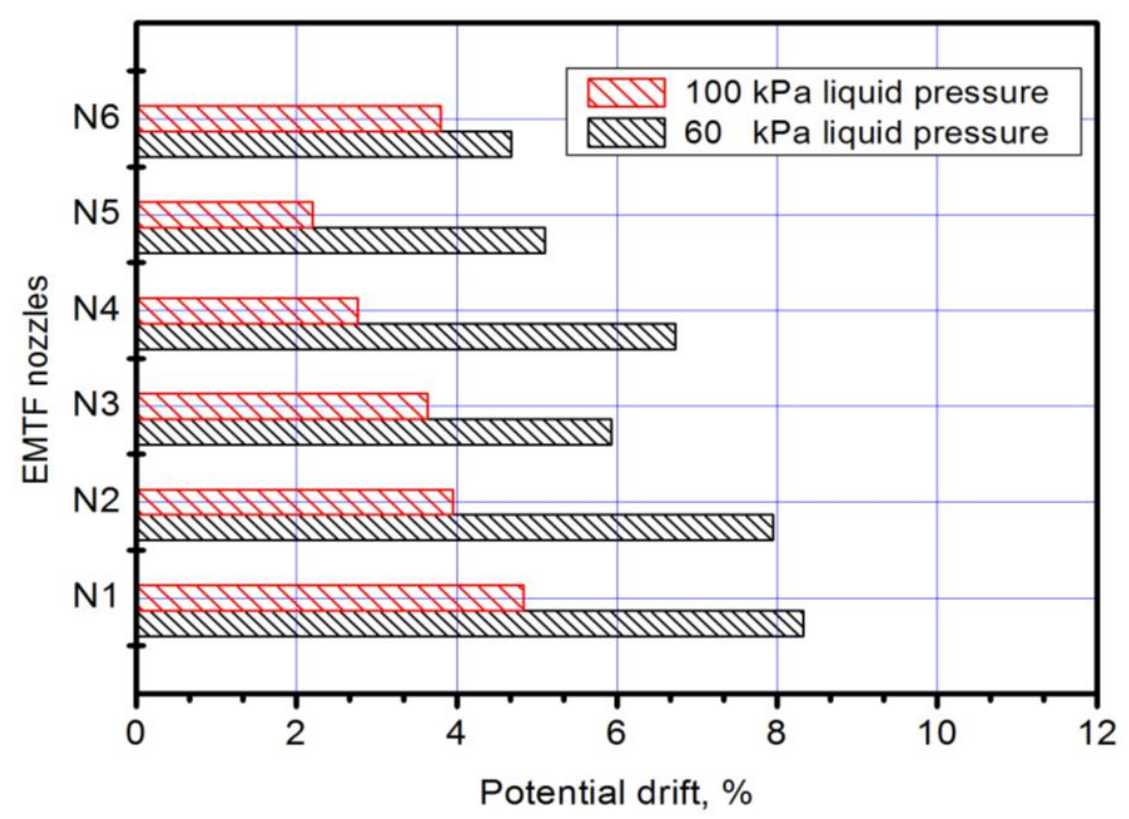

Fig. 6: Effect of Liquid spray pressure on potential drift parameter for different EMTF nozzles 


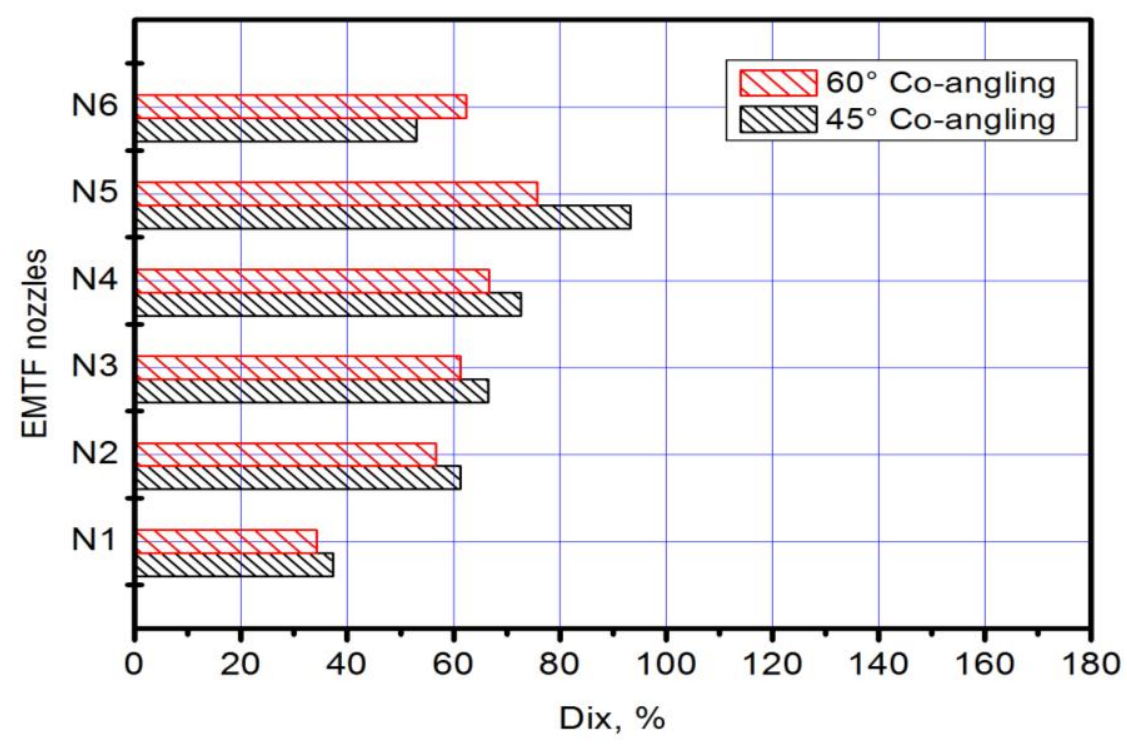

Fig. 7: Effect of co-angling on the DIX parameter for different EMTF nozzles

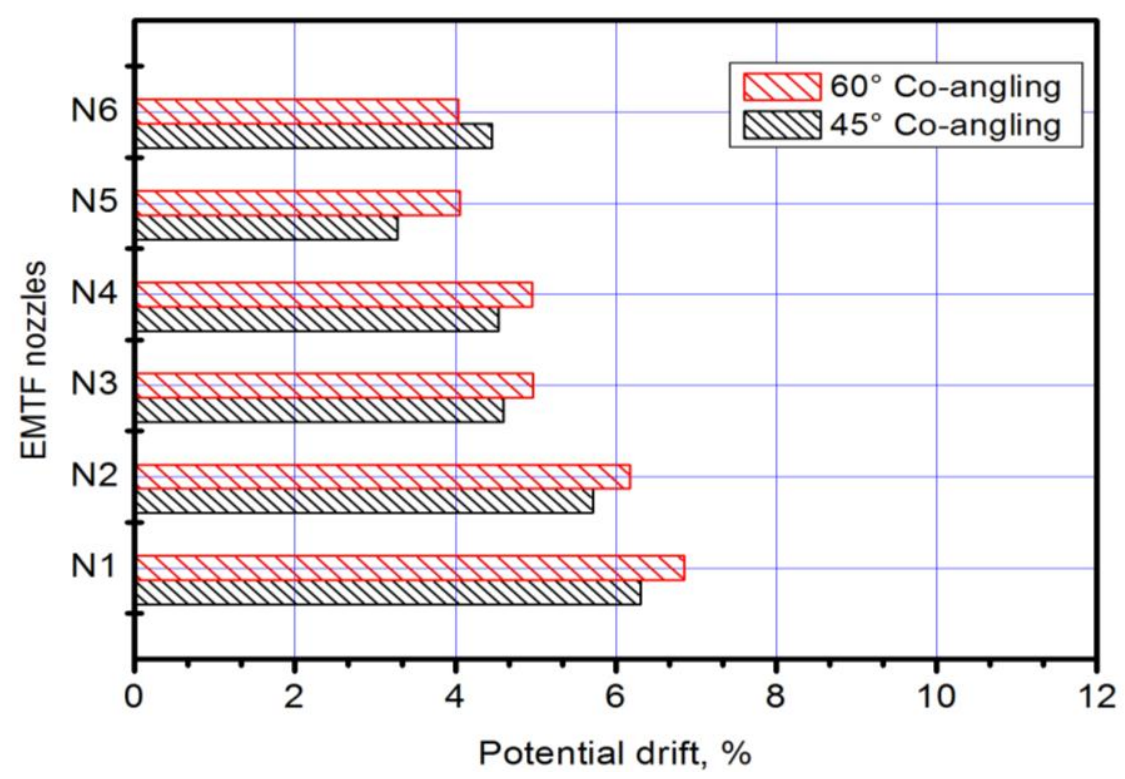

Fig. 8: Effect of co-angling on the potential drift parameter for different EMTF nozzles 


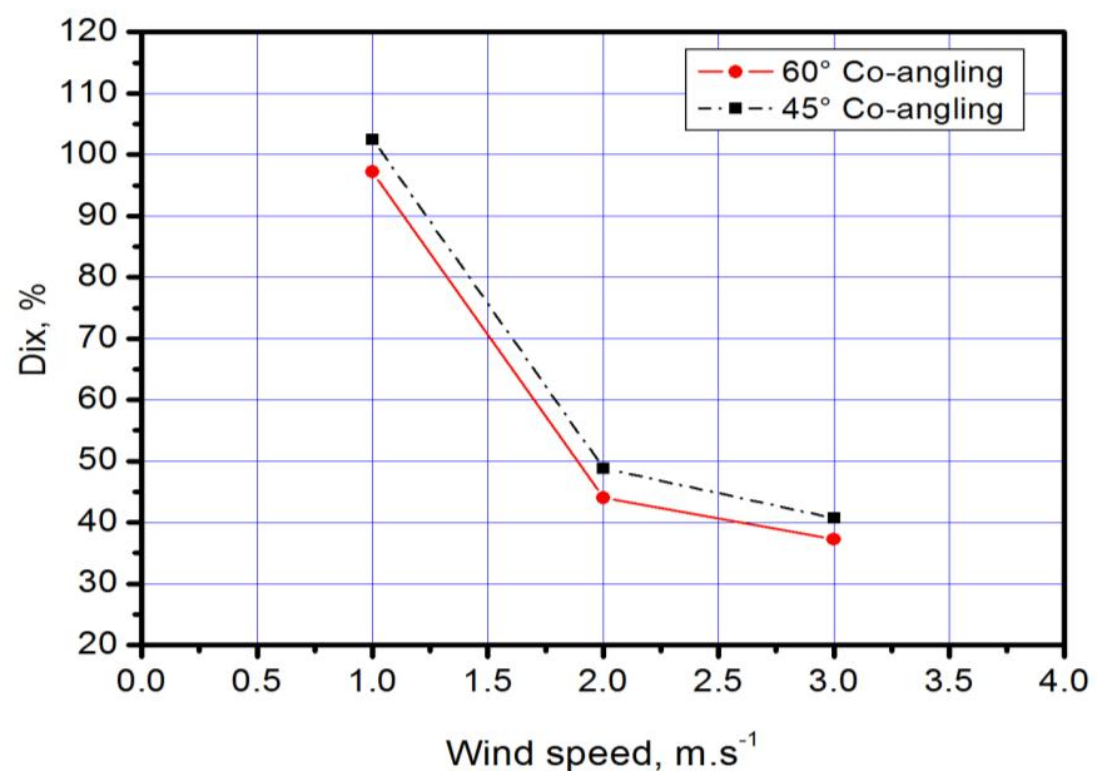

Fig. 9 Effect of wind speed and co-angling on the DIX parameter for different EMTF nozzles

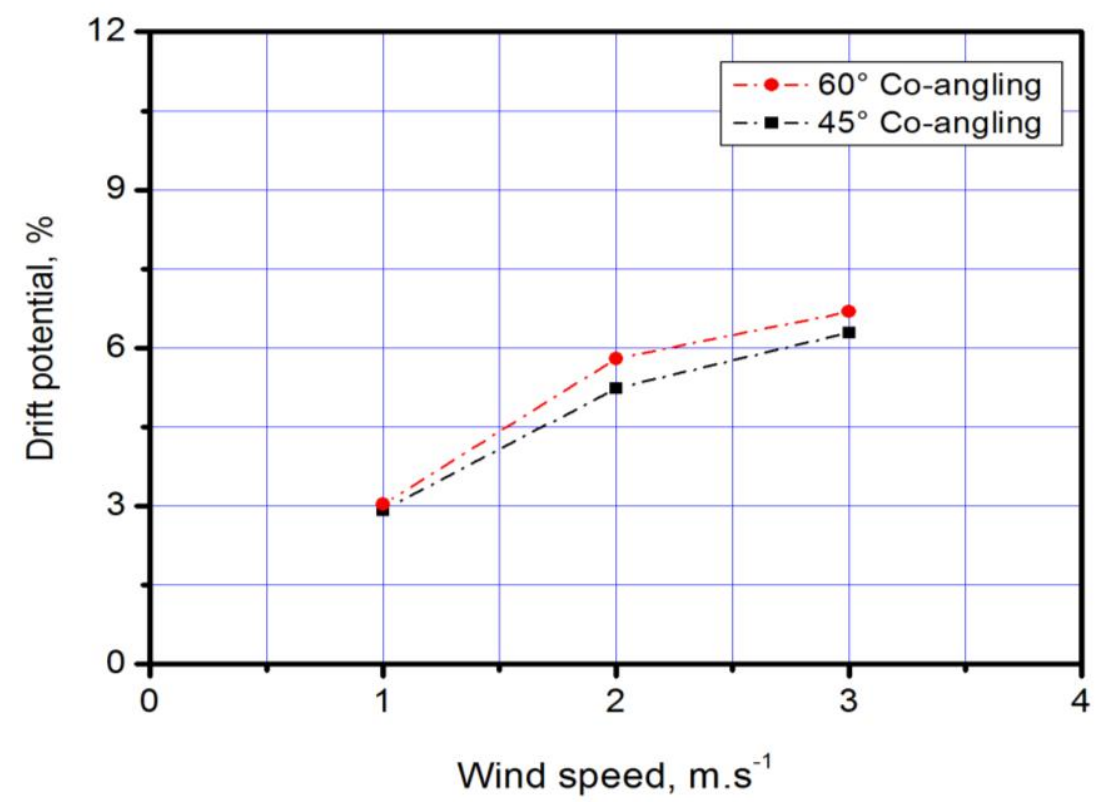

Fig. 10: Effect of wind speed and co-angling on the potential parameter for different EMTF nozzles 
Table 6: The effect of the interaction of EMTF nozzles, co-angling, spray pressure and wind speed on Dix and the potential drift parameter

\begin{tabular}{|c|c|c|c|c|c|c|c|c|}
\hline \multirow{3}{*}{ Nozzles } & \multirow{3}{*}{$\begin{array}{c}\text { Co- } \\
\text { angling }\end{array}$} & \multirow{3}{*}{$\begin{array}{c}\text { Pressure, } \\
\mathrm{kPa}\end{array}$} & \multicolumn{6}{|c|}{ Wind speed } \\
\hline & & & \multicolumn{2}{|c|}{$1 \mathrm{~m} \mathrm{~s}^{-1}$} & \multicolumn{2}{|c|}{$2 \mathrm{~m} \mathrm{~s}^{-1}$} & \multicolumn{2}{|c|}{$3 \mathrm{~m} \mathrm{~s}^{-1}$} \\
\hline & & & $\begin{array}{c}\text { DIX, } \\
\%\end{array}$ & $\begin{array}{c}\text { Drift, } \\
\%\end{array}$ & $\begin{array}{c}\text { DIX, } \\
\%\end{array}$ & $\begin{array}{c}\text { Drift, } \\
\%\end{array}$ & $\begin{array}{c}\text { DIX, } \\
\%\end{array}$ & $\begin{array}{c}\text { Drift, } \\
\%\end{array}$ \\
\hline \multirow{4}{*}{ N1 } & $45^{\circ}$ & 60 & 29.6 & 7.4 & 27.7 & 7.9 & 25.2 & 8.7 \\
\hline & $45^{\circ}$ & 100 & 48.7 & 4.5 & 46.5 & 4.7 & 46.3 & 4.7 \\
\hline & $60^{\circ}$ & 60 & 27.1 & 8 & 25.4 & 8.6 & 23.1 & 9.4 \\
\hline & $60^{\circ}$ & 100 & 44.7 & 4.9 & 42.6 & 5.1 & 42.5 & 5.1 \\
\hline \multirow{5}{*}{$\mathrm{N} 2$} & $45^{\circ}$ & 60 & 83.3 & 2.6 & 23.4 & 9.3 & 19.8 & 11 \\
\hline & $45^{\circ}$ & 100 & 150.1 & 1.5 & 54.1 & 4 & 37.3 & 5.9 \\
\hline & $60^{\circ}$ & 60 & 77.1 & 2.8 & 21.6 & 10.1 & 18.4 & 11.9 \\
\hline & $60^{\circ}$ & 100 & 139.0 & 1.6 & 49.8 & 4.4 & 34.5 & 6.3 \\
\hline & $45^{\circ}$ & 60 & 94.3 & 2.3 & 32.1 & 6.8 & 27.4 & 8 \\
\hline \multirow{2}{*}{ N3 } & $45^{\circ}$ & 100 & 144.4 & 1.5 & 59.2 & 3.7 & 41.3 & 5.3 \\
\hline & $60^{\circ}$ & 60 & 87.2 & 2.5 & 29.5 & 7.4 & 25.2 & 8.6 \\
\hline \multirow{5}{*}{ N4 } & $60^{\circ}$ & 100 & 133.2 & 1.6 & 54.4 & 4 & 38.1 & 5.7 \\
\hline & $45^{\circ}$ & 60 & 63.3 & 3.5 & 28.1 & 7.8 & 27.1 & 8 \\
\hline & $45^{\circ}$ & 100 & 187.7 & 1.2 & 71.7 & 3 & 58.5 & 3.7 \\
\hline & $60^{\circ}$ & 60 & 58.2 & 3.8 & 24.7 & 8.5 & 25.8 & 8.8 \\
\hline & $60^{\circ}$ & 100 & 172 & 1.3 & 65.3 & 3.3 & 53.6 & 4.1 \\
\hline \multirow{4}{*}{ N5 } & $45^{\circ}$ & 60 & 77.7 & 2.8 & 38.1 & 5.4 & 40.8 & 5.7 \\
\hline & $45^{\circ}$ & 100 & 219.5 & 1.1 & 93.2 & 2.3 & 90.1 & 2.4 \\
\hline & $60^{\circ}$ & 60 & 76.3 & 2.9 & 32.1 & 6.8 & 30.4 & 7.2 \\
\hline & $60^{\circ}$ & 100 & 173.2 & 1.3 & 74.4 & 2.9 & 68.4 & 3.2 \\
\hline \multirow{4}{*}{ N6 } & $45^{\circ}$ & 60 & 60.4 & 3.6 & 51.3 & 4.3 & 30.7 & 7.1 \\
\hline & $45^{\circ}$ & 100 & 71.1 & 3.1 & 60.7 & 3.6 & 43.8 & 5 \\
\hline & $60^{\circ}$ & 60 & 55.8 & 3.9 & 52.7 & 4.6 & 47 & 4.6 \\
\hline & $60^{\circ}$ & 100 & 122.9 & 1.8 & 55.5 & 3.9 & 40.2 & 5.4 \\
\hline DIX & & 2.5529 & & for drift & & & 2420 & \\
\hline $5 \%$ LSD f & IX & 14.259 & & $\%$ LSD fo & Irift & & 8126 & \\
\hline
\end{tabular}

This means that the N5 (Lechler FT 5-608 \& XR110ß03 VK) nozzle may be able to reduce the low fallout airborne volume flux compared to Standard ISO nozzle and N1 nozzle which produced at $43.7 \%$ DIX value. The airborne values for N5 (Lechler FT 5-608 \& XR110-03 VK) nozzle were $0.71 \mathrm{ml} / \mathrm{s} . \mathrm{mm}, 0.07$ and $0.046 \mathrm{ml} / \mathrm{s} . \mathrm{mm}$ at ground level (zero 
$\mathrm{mm}), 500 \mathrm{~mm}$ and $600 \mathrm{~mm}$ height, respectively. The airborne values for N1 (Lechler FT 5-608 \& XR110-03 VK) nozzle were $2.81 \mathrm{ml} / \mathrm{s} . \mathrm{mm}$, 0.17 and $0.068 \mathrm{ml} / \mathrm{s} . \mathrm{mm}$ at ground level (zero $\mathrm{mm}$ ), $500 \mathrm{~mm}$ and 600 $\mathrm{mm}$ height, respectively.

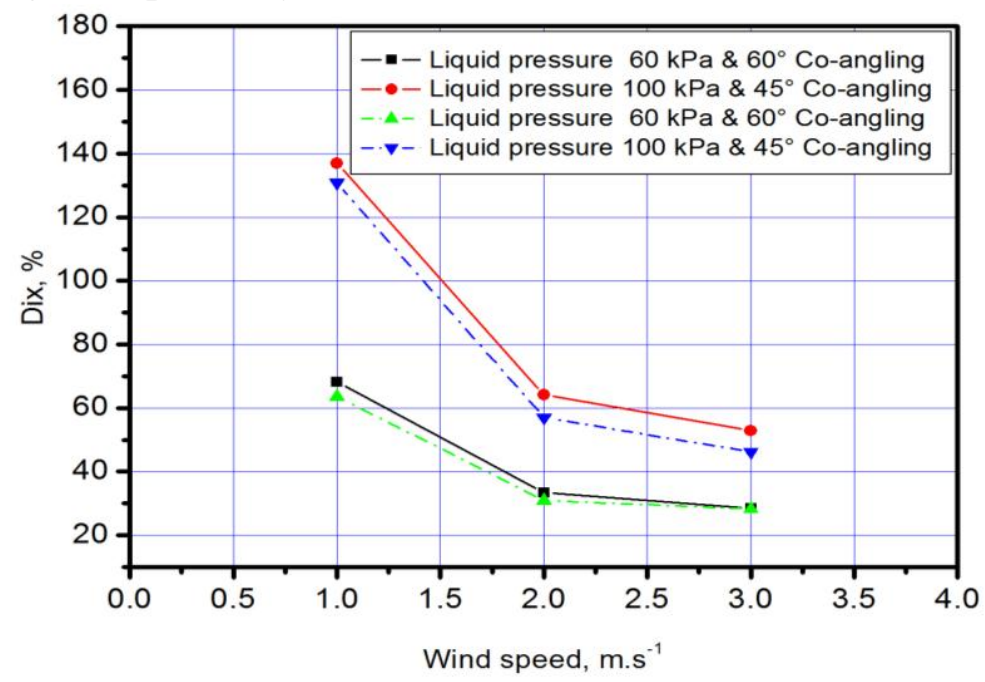

Fig. 11: Effect of wind speed and co/angling on the DIX parameter for different EMTF nozzles

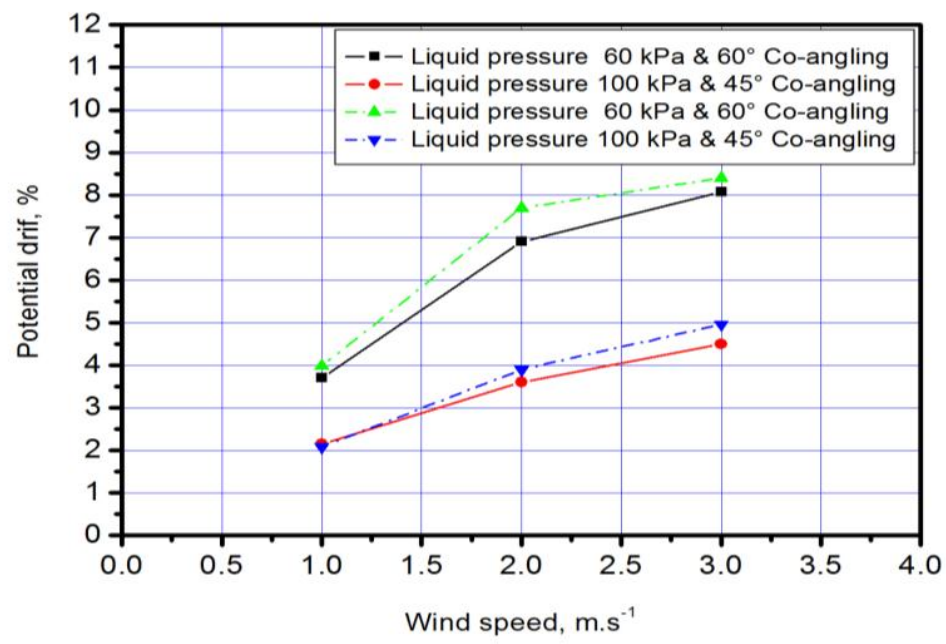

Fig. 12: Effect of wind speed, co-angling and spray liquid pressure on the potential drift parameter for different EMTF nozzles 


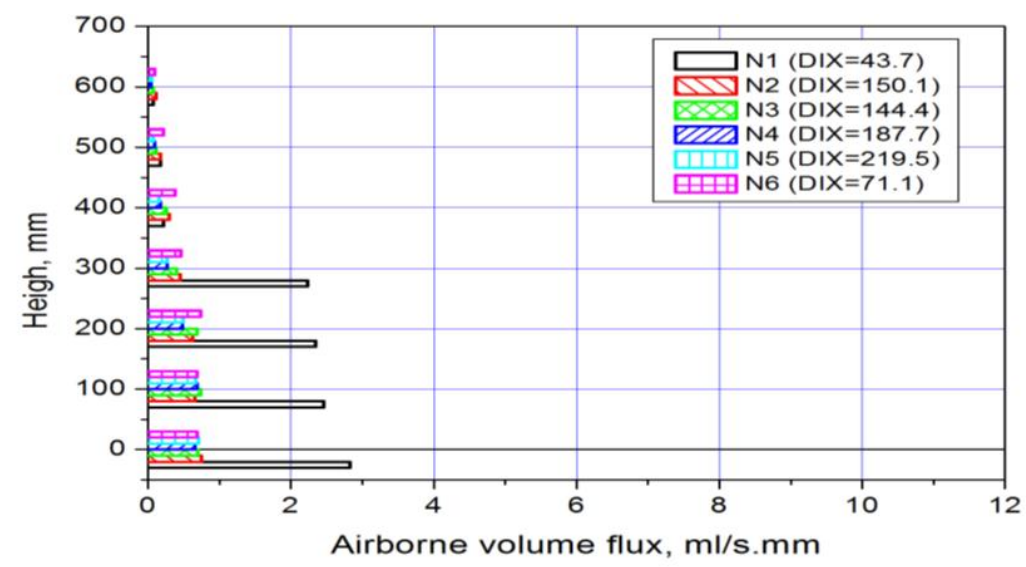

Fig. 13: Display the airborne volume flux for different EMTF nozzles at different measuring height position.

\section{CONCLUSION}

Wind tunnel measurements were used to measure airborne and fallout spray volumes under directly comparable and repeatable conditions using single and static nozzles. Based on these measurements, DIX and vertical drift which express the percentage reduction of the drift potential compared with the reference spraying were calculated using DIX and vertical drift. The wind tunnel provided a method to assess spray drift of EMTF nozzles. The existing classification scheme for drift from standard fan nozzles could be used as a reference for assessment of the drift behavior of EMTF nozzles (and potentially for other spray generators).In most cases, EMTF nozzles produced lather drift than the standard flat fan nozzles under comparable conditions. However, at a low wind speed and $100 \mathrm{k}$ Pa liquid pressure, EMTF nozzles lower drift than the standard fan nozzles.

In general, the results showed the expected fallout and airborne profiles. for the same nozzle size and spray pressure, DIX values were generally higher for the N5 nozzles tested followed by the standard flat-fan nozzles. The effect of nozzle type was more important for EMTF nozzle. Besides nozzle type, the co-angling of the nozzle also influenced liquid spray pressure. The N1 nozzle (FT 5-608 \& TT110-03 POM) produced the highest values for drift compared to both the standard flat-fan and the N5 (FT 5-608 \& XR110-03VK) nozzles at a 
constant spray pressure. In the statistical analysis, the all interaction of the co-angling $45^{\circ}$ and $100 \mathrm{kPa}$ gave the highest values of DIX and lowest values of the vertical drift In this case study, the co-angling $45^{\circ}$ in EMTF nozzles may be the best co-angling which could be reducing the drift potential for all combined of EMTF nozzles.

\section{Acknowledgements:}

The authors would like to acknowledge the JKI, Applied Technique Division in Braunschweig, Germany and Research Unit staff for their support and use of the wind tunnel to complete this study. Special thanks are offered to Prof. Dr. H. Ganzelmeier, Mr. S. Nolte, and Mr. L. Oelman in JKI and Dr. R. Heinkel from Lechler Company.

\section{REFERENCES}

Derksen, R.C. and R.L. Gray (1995): Deposition and air speed patterns of air-carrier apple orchard sprayers. Transactions of ASAE 38(1):511.

Fox, R.D., S.M. Hussein, D.L. Reichard, R.D. Brazee, and F.R. Hall (1994): A Comparison of spray drift deposited on ground and airborne spray collectors and on soybean plants. Fruit Crops 1994: A Summary of Research, OSU/OARDC Res Circular 298, 109-114.

Ganzelmeier, H. (1993): Drift of plant protection products in field crops, vineyards, orchards and hops.

Ganzelmeier, H., D. Rautmann, G. Backer, K.W. Eichhorn, R. Ipach, E. Kersting, H. Koch, F.-O. Ripke, N. and K. Schmidt (1992): Guidelines for checking plant protection equipment. Part VII: Measuring direct drift when applying liquid plant protection products. Federal Biological Research Centre for Agriculture and Forestry, Braunschweig, Germany.

Gobel, B and S. Pearson (1993): Drift Reduction by spray nozzle techniques. Second International Symposium on Pesticide Application Techniques. 219-226.

Helck, C. and A. Herbst, (1998): Drift-Potential-Index - eine neue Kennzahl zur Beurteilung von Pflanzenschutzdüsen hinsichtlich ihres Abtriftpotentials (Drift-Potential-Index - a new parameter for 
the evaluation of agricultural nozzles concerning their drift potential). Nachrichtenbl. Deut. Pflanzenschutzd. 50(9): 225-232.

Herbst, A. (2001). Droplet sizing on Agricultural sprays - A comparison of measuring systems using a standard droplet sizing classification system. Proc. ILASS - Europe Zurich, Switzerland.

ISO/DIS 22856 (2007). International standard: equipment for crop protection - laboratory measurement methods of spray drift - wind tunnels.

Miller P. C. H. (1993): Spray drift and its measurement. In: Application Technology for Crop Protection (Matthews G A; Hislop E C eds), pp. 101-122. CAB International, Wallingford, Oxon, United Kingdom.

Nuyttens D; K. Baetens; M. De Schampheleire and B. Sonck (2007b): Effect of nozzle type, size and pressure on spray droplet characteristics.J. Biosystems Engineering, 97(3), 333-345. doi:10.1016/j.biosystemseng.2007.03.001.

Nuyttens D; M. De Schampheleire; K. Baetens and B. Sonck (2007a): The influence of operator controlled variables on spray drift from field crop sprayers. Transactions of the ASABE, 50(4), 1129-1140.

Ozkan, H.E. and R.C. Derksen. (1998): Extension Fact Sheet Effectiveness of Turbodrop and Turbo TeeJet Nozzles in Drift Reduction. The Ohio State University, Food, Agricultural and Biological Engineering Department. AEX 524-98.

Reichard, D. L., R. D. Fox, R. D. Brazee and F. R. Hall (1979): Air velocities delivered by orchard air sprayers. Transactions of ASAE 22(1):69-74, 80.

Reichard, D.L., B.R. Tennes, B.L. Burton and G.K. Brown (1982): Experimental orchard sprayer. Transaction of ASAE 25(1):33-37, 41.

Salyani, M. and R. P. Cromwell (1992): Spray drift from ground and aerial applications. Transactions of ASAE 35(4):1113-1120.

SDTF (1997): A Summary of Ground Application Studies, Stewart Agricultural Research Services, Inc. P.O. Box 509, Macon, MO. 63552. 
Sehsah E.M.E. (2005): Application techniques for biological crop protection in Orchards and vineyards. Ph.D thesis, Hohenheim University, ISDN: 3-86186-484-3 Vorlag Grauer Stuttgart Germany.

Sehsah E.M.E. and S. Kleisinger (2007): Effect of low pressure liquid atomizers usage in biological pest control, Misr J.Ag.Eng., 24 (1): $62-74$.

Sehsah, E., G. Baecker and S. Kleisinger (2004c): Evaluation of an experimental sprayer with rotary atomizers by air characteristics, soil sedimentation, deposition and vertical drift. International Conference Environmentally Friendly Spray Application Techniques 4-6 October, 2004c - Warsaw, Poland.

Smith, D.B., L.E. Bode, and P.D. Gerard. 2000. Predicting Ground Boom Spray Drift. Trans. ASAE 43(3):547-553.

Walklate P J; P C H.Miller; A J Gilbert (2000): Drift classification of boom sprayers based on single nozzle measurements in a wind tunnel. Aspects of Applied Biology, 57, 49-57.

Walklate P J; P C H.Miller; M. Rubbis; C R. Tuck (1994): Agricultural nozzle design for spray drift reduction. In: Proceedings ILASS-94, Rouen, France, pp. 851-858.

Williams, W.L., D.R. Gardisser, R. E. Wolf, and R. W. Whitney (1999): Field and Wind Tunnel Droplet Spectrum Data for the CP Nozzle. ASAE Paper No. AA99-007. St Joseph, MI.: ASAE.

Wolf, R. and C. Minihan (2001): Comparison of Drift Potential for Venturi, Extended Range, and Turbo Flat-fan Nozzles. ASAE Paper No. MC01-108. St. Joseph, MO.: ASAE Sponsored.

Wolf, R., (2000): The Influence of Changing Application Volumes on Droplet Size Using Blended Pulse Spraying Technology. ASAE Paper No. 001122. St. Joseph, MI.: ASAE.

Wolf, R., D. Peterson, and C. Minihan (1999): Comparisons of off-target deposits for conventional postemergence spray nozzles and venturi nozzles. Proceedings North Central Weed Science Society. 54:70.

Wolf, R., D. Peterson, and C. Minihan (2001): Influence of Nozzle Type and Spray Pressure on Droplet Size. Proceedings North Central Weed Science Society. 56:Paper No. 142. 
Wolf, R.E., D.R. Gardisser, and W. L. Williams (1999): Spray Droplet Analysis of Air Induction Nozzles Using WRK DropletScan Technology. ASAE Paper No. 991026. St. Joseph, MI.: ASAE.

Womac, A.R., J.C. Goodwin, and W.E. Hart (1997): Tip Selection for Precision Application of Herbicides, University of Tennessee CES. Bulletin 695.

\section{الملخص العربي}

\section{الانجراف الناتج عن الفواني ذات الضغط المنخفض و الخفيع الخفاس الخارجى لمائعين على أساس قياسات نفق الهوات الهواء

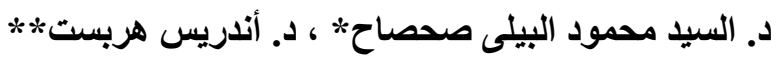

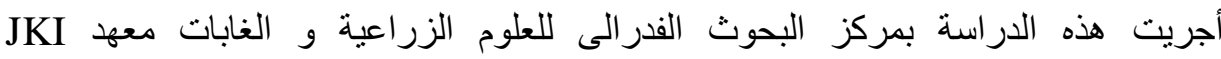

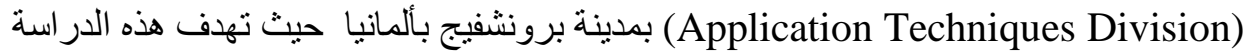

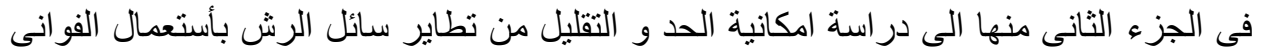

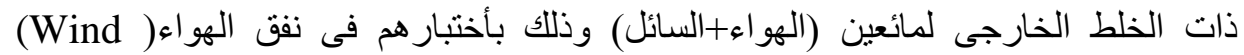
tunnel Airborne volume flux

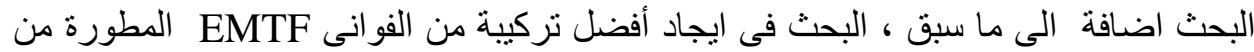

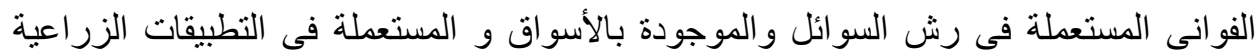

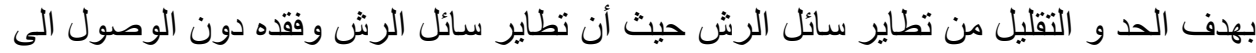

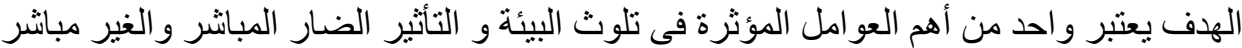

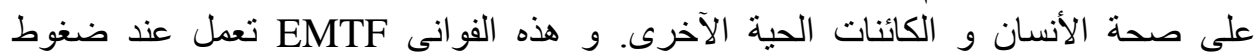

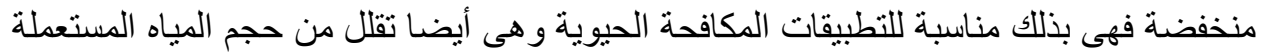

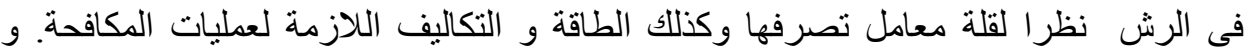

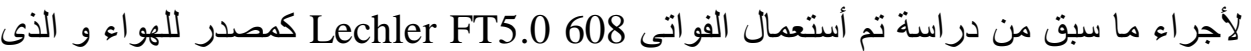

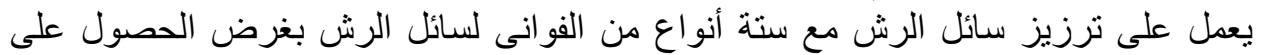

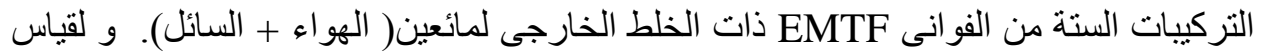

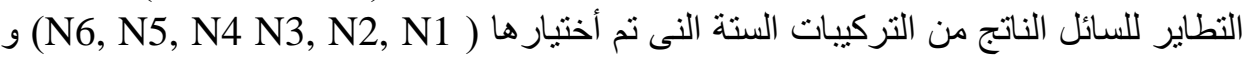

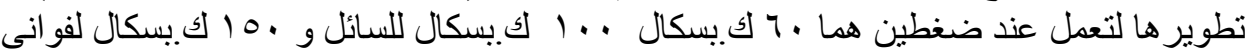

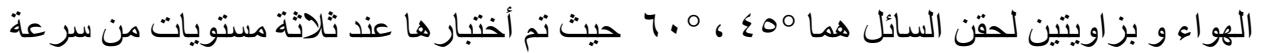

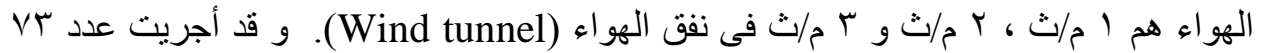

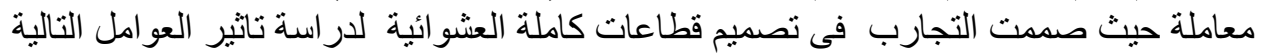

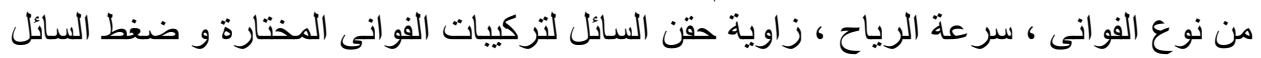

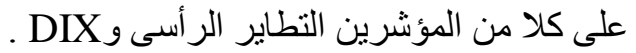

* مدرس بقسم الهندسة الزر اعيةـ كلية الزر اعة- جامعة كفر الثيخ- مصر.

** باحث بمركز البحوث الفدر الى للعلوم الزر اعية و الغابات معهد (JKI) بمدينة برونشفيج بألمانيا 
و لق أستعملت الفو انى من نوع Hardi ISO 03 عند ضغط سائل . . ب كيسكال كفو انى قياسية DIX Standard flat fan nozzles

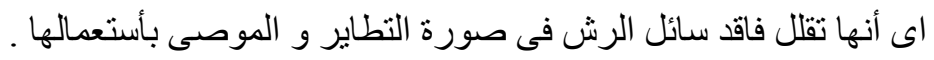

أهم النتائج المتحصل عليها:

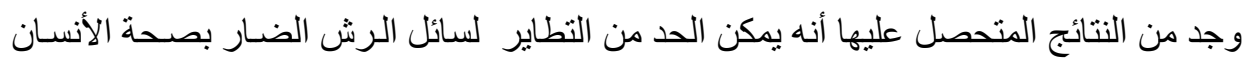

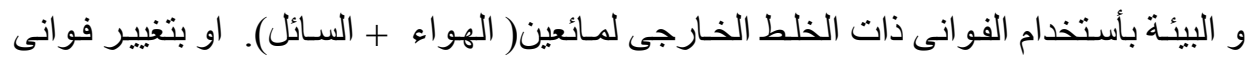

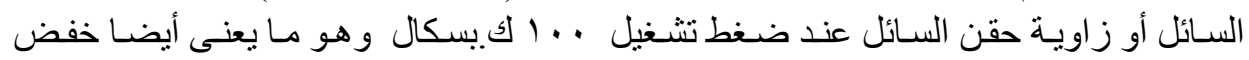

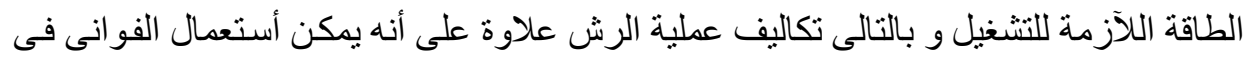

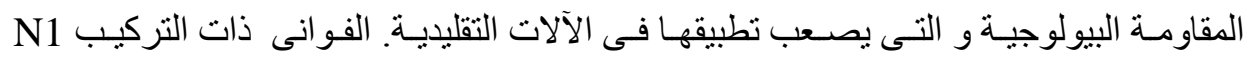
(TT110-03+ Lechler FT 5 - 608)

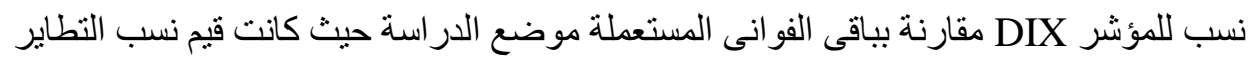

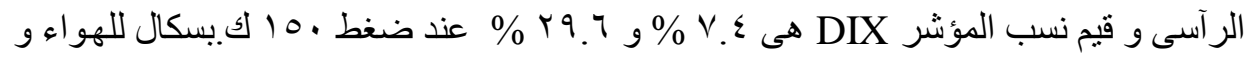

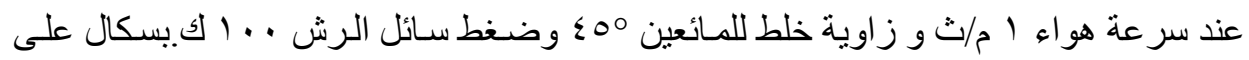

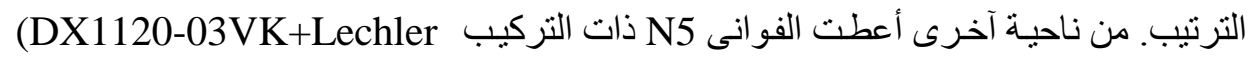

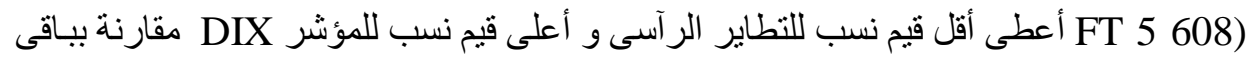

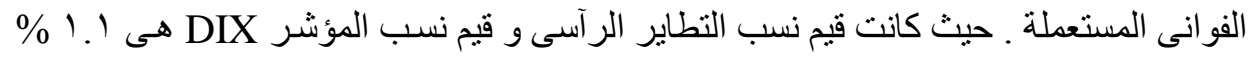

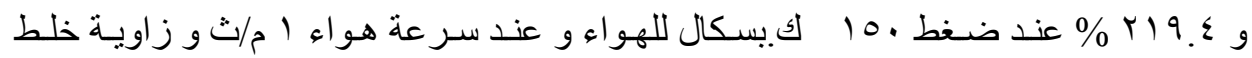

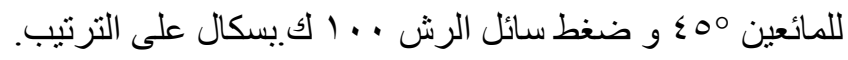

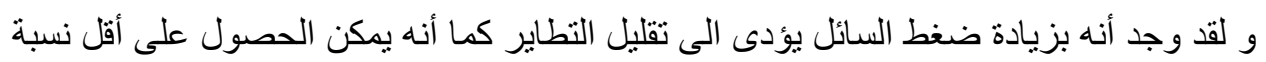

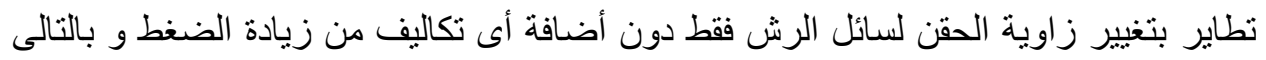

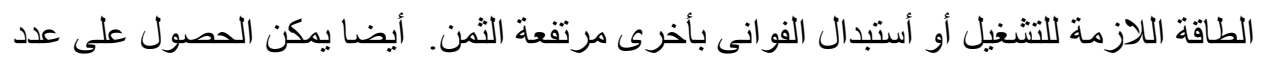

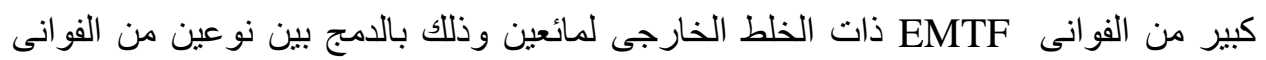

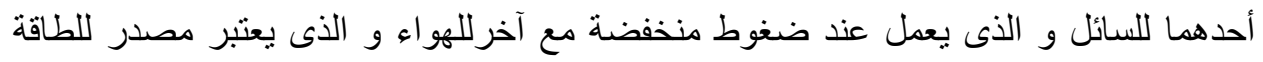

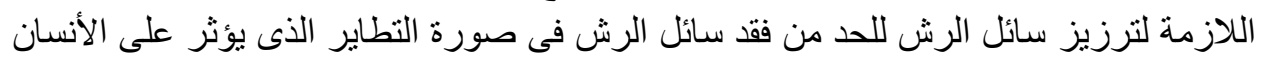

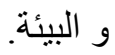

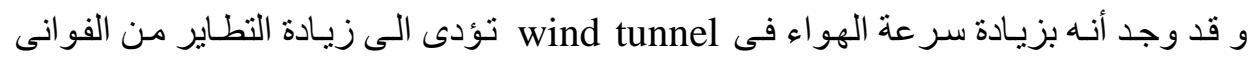
EMTF

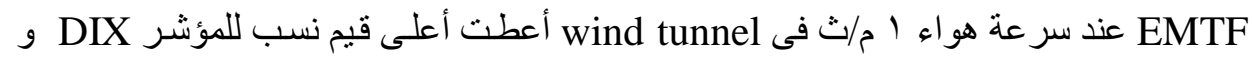

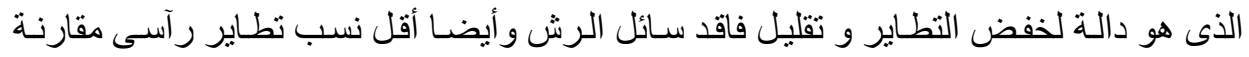

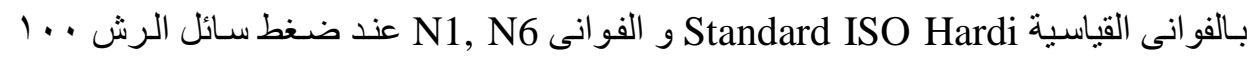
ك.بسكال و زاوية حقن 0 ؛ درجة.

بينما أعطت الفوانى N5 ذات التركيب (Lechler FT 5-608 \& XR110-03 VK) أعلى

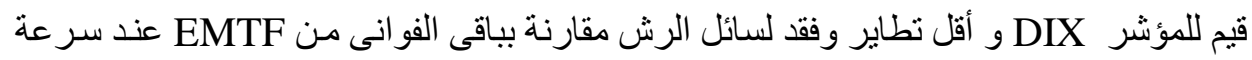

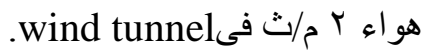

